\title{
Effectiveness of the Mechanisms of Fraud Prevention and Detection in Nigeria
}

\author{
Eme J. Efiong \\ Department of Accounting, \\ University of Calabar, P. M. B. 1115, Calabar, Nigeria \\ Inyang 0. Inyang \\ Department of Accounting, \\ University of Calabar, P. M. B. 1115, Calabar, Nigeria \\ Udeme Joshua \\ Department of Accounting, \\ University of Calabar, P. M. B. 1115, Calabar, Nigeria
}

\begin{abstract}
Whereas the problem of fraud is a global one, the rate and extent to which it is perpetrated in Nigeria, particularly in the public sector, is quite high and alarming. Literature reveals that different fraud prevention and detection mechanisms are being adopted to combat the menace of fraud. Forensic accounting techniques appears to be the most effective and are currently used in most developed countries of the world. However, the extent to which forensic accounting techniques are being applied in fraud prevention and detection in Nigeria is not known.This study was therefore aimed at investigating the mechanisms of fraud prevention and detection, and their levels of effectiveness in Nigeria.The study involved the collection of quantitative data from accounting practitioners. The questionnaire served as the survey instrument.The study identified several fraud prevention and detection mechanisms that are currently used in Nigeria, such as systems of internal controls, operational audits and corporate code of conduct. Students' t-test indicates a significant difference between the perceived effectiveness and actual usage of fraud prevention and detection mechanisms in Nigeria. It was further discovered that the most effective mechanisms, like the forensic accounting techniques, are the least used in fraud prevention and detection. This implies that the current mechanisms of fraud prevention and detection are not proactive in dealing with the fraud menace. The study recommended that proactive measures in terms of mechanisms be employed in tackling fraud manace in Nigeria.
\end{abstract}

Keywords: Fraud, Fraud prevention mechanisms, fraud detection mechanisms, Fraud manace in Nigeria, forensic accounting techniques

\section{INTRODUCTION}

The role of auditor in fraud prevention and detection was questioned as a result of the rise in financial scandals at the beginning of the twenty-first century, associated with increased fraud incidence and awareness (Bhasin, 2013). Hogan et al( 2008) argued that the rise and rate of occurrence of financial fraud have not shown any decline since the Sarbanes-Oxley Act was passed in 2002. To respond to these modern organised frauds there has been calls for the skills of accountants with non-traditional methods.

According to Ratlift et al (1996), fraud is defined as activities carried out to obtain money, property or services, to avoid payment or services or to secure personal or business 
advantages in favour of the fraudster. The International Standards for Professional Practice of Internal Auditing, (2002), opined that these activities may not necessarily dependent on violence or the use of physical force. Adefila, Kasum and Olaniyi (2005), have argued that fraud risk increases as a result of inadequate, ineffective, weak, absent or non-existence of fraud preventive and detective mechanisms. By implication, government agencies are to use the most effective fraud prevention and detection mechanisms (Kasum, 2009).

Fraud in the Nigerian economy has done so much of untold harm to the citizenry. Moreover, Jeremiah, (2006) noted that in Nigeria, fraud in both the public and private sectors are major factors of the dwindling economy. According to Hamilton and Gabriel (2012:112), "fraud and related ills have caused instability in the economy resulting to a high mortality rate of business organisations and the consequent losses of revenue" in Nigeria.

This study investigates the mechanisms of fraud prevention and detection as it is commonly used in Nigeria. Further, perceived levels of effectiveness of fraud prevention and detection methods used in Nigeria were examined. Moreover, it brings to fore significant difference in the actual use of fraud prevention and detection methods and their level of effectiveness.

The sophisticated nature of fraud in Nigeria (Adefilia, Kasum, and Olaniyi 2006; Okunbor and Obaretin 2010; Akindele, 2011) calls for an investigation into the methods of fraud prevention and detection that are in common usage in the country. Literature has revealed that the most effective fraud prevention and detection mechanisms are the least used in combating the menace of fraud (Bierstaker, Brody and Pacini, 2006). However, it is not clear if significant difference exist between the perceived effectiveness of the fraud prevention and detection mechanisms and their actual usage in fraud management. The questions then are what are the common fraud prevention and detection mechanisms and their level of effectiveness in Nigeria? Is there any significant difference in the perceived effectiveness of fraud prevention and detection mechanisims and their actual usage in Nigeria?

\section{Traditional Mechanisms of Fraud Prevention and Detection}

Ttraditional mechanisms of fraud prevention and detection in an organization before or after the incidence have been fashioned include internal control systems, operational audits, code of conduct and reference checks on employees (Bierstaker, Burnaby and Hass 2004 and Bierstaker, Brody and Pacini 2006).

Sydney, (1986) describes internal control as checks, whether financial or otherwise, which is established by management of any organisation, to enable work done in an orderly manner and for the safety, security and reliability of records. These can only be obtained as responsibilities of accountants and auditor with reference to fraud. Fraud maybe discovered as internal auditor performs his task, but this maybe hinderd as management has 'significant influence over an internal auditor's commitment to detect fraud' (Ramaswamy, 2007:33). Hamilton and Gabriel (2012:114) argue that, "accountant and auditors have often been exalted to be the leaders in fraud prevention by employing their skills in designing 'tight' control systems."

Hamilton and Gabriel (2012) observe that internal control systems strategy is at best a shortrun solution to a large and pervasive problem of fraud. Worse still, effective long-run measures of fraud prevention are not only complex, but also difficult (Robertson, 1976). Nnamdi (1991) claims that, the ineffectiveness of internal control measures are due to weakness in staff policy 
and control, operational procedures and management's attitude. Hence, internal controls are not perceived as an effective mechanism for fraud prevention and detection. This Ramaswamy, 2007:33) puts in a more concise way 'fraud is no longer wthat internal or external auditors can guard against with their periodic audit'.

\section{Forensic Accounting Mechanisms of Fraud Prevention and Detection}

Forensic accounting mechanisms such as benford's law, data minimg etc have been used in fraud prevention and dectection as defined by Mehta and Mather (2007), have disscused the operational workings of these techniques.Generally, forensic accounting approaches include the proactive and the reactive ones. The use of any of these approaches depends very much on the existing circumstances. The proactive approach is asserted to be a universally tactical approach as it aggressively targets types of fraud, searches for indicators, symptoms, or red flags (Levanti, 2001). The Bendford's digital analysis (Nigrini, 1999); the breakpoint technique (Hassibi, 2000); the strategic fraud detection technique (Albrecht and Albrecht, 2004); fraud hypothesis testing technique (Albrecht et al. 2004) and the five-step detection technique (Ernst and Young, 2006) are generally proactive forensic accounting techniques because they comply with the detective philosophy which aims at catching fraud before it occurs. On the other hand, the reactive approach, favours the philosophy of waiting to see the fraud taking place first and then arrest it. This may involve the use of electronic equipment, such as the closed circuit television (CCTV) or digital and mobile cameras (Njanike, Dube and Mashayanye 2009).

Many empirical studies have been carried out on the application of forensic accounting techniques in fraud investigation for instance Njanke, Dube and Mashayanye (2009) in their study on the effectiveness of forensic auditing in detecting, investigating, and preventing bank frauds, sought to find out level to which the forensic auditors are able to fulfil this mandate and investigate problems that hinder forensic auditors to make progress in their operations in developing countries. Their study made use of questionnaires, personal interviews, and document review as the instruments for data collection. Using a sample of thirty forensic auditors from thirteen commercial banks, four building societies and four audit firms in Zimbabwe, it was found that the forensic auditing departments suffer from multiple challenges. Amongst these challenges were lack of material resources, lack of technical know-how, interference from management, and unclear recognition of the profession.

However, Okunbor and Obaretin (2010) conducted a study on effectiveness of the application of forensic accounting services in Nigerian corporate organisations and came up with a different result. The main objectives of their study were to establish whether the application of forensic accounting services by corporate organisations is effective in deterring fraudulent practices and to find out the perception of the users of forensic accounting services, in Nigeria. The research was conducted using the mixed methods approach, involving the combination of structured interviews and questionnaire. Ten companies were selected as the sample for the study from the population of companies quoted on the Nigerian Stock Exchange. Their study revealed that the application of forensic accounting services by corporate organisations in Nigeria is not effective in curbing fraudulent activities.

While their result is consistent with the findings of Okoye and Jugu (2009), who examined the effectiveness of fraud deterrence policies in the banking sector of the Nigerian economy, it is rather inconsistent with the general belief on the importance forensic accounting. They do not also agree with the bulk of the literature from elsewhere that as reviewed in this work. This particularly makes the fraud situation in Nigeria to be complex and calls for further studies. 


\section{METHOD OF STUDY}

This study was conducted on accounting practitioners in the public service in Nigeria.

Considering the geographical spread of the population of this study (accounting practitioners in public service), the multi-stage sampling technique was adopted. The multi-stage sampling 'is a development of cluster sampling' (Saunders, Lewis and Thornhill, 2009: 231) which can be used with geographically dispersed populations to save time and cost.

Nigeria has 36 states with a Federal Capital Territory (FCT). These states and the FCT are currently stratified into six (6) geo-political zones (Fig. 1and 2). These formed the first set of clusters (six) for this study.

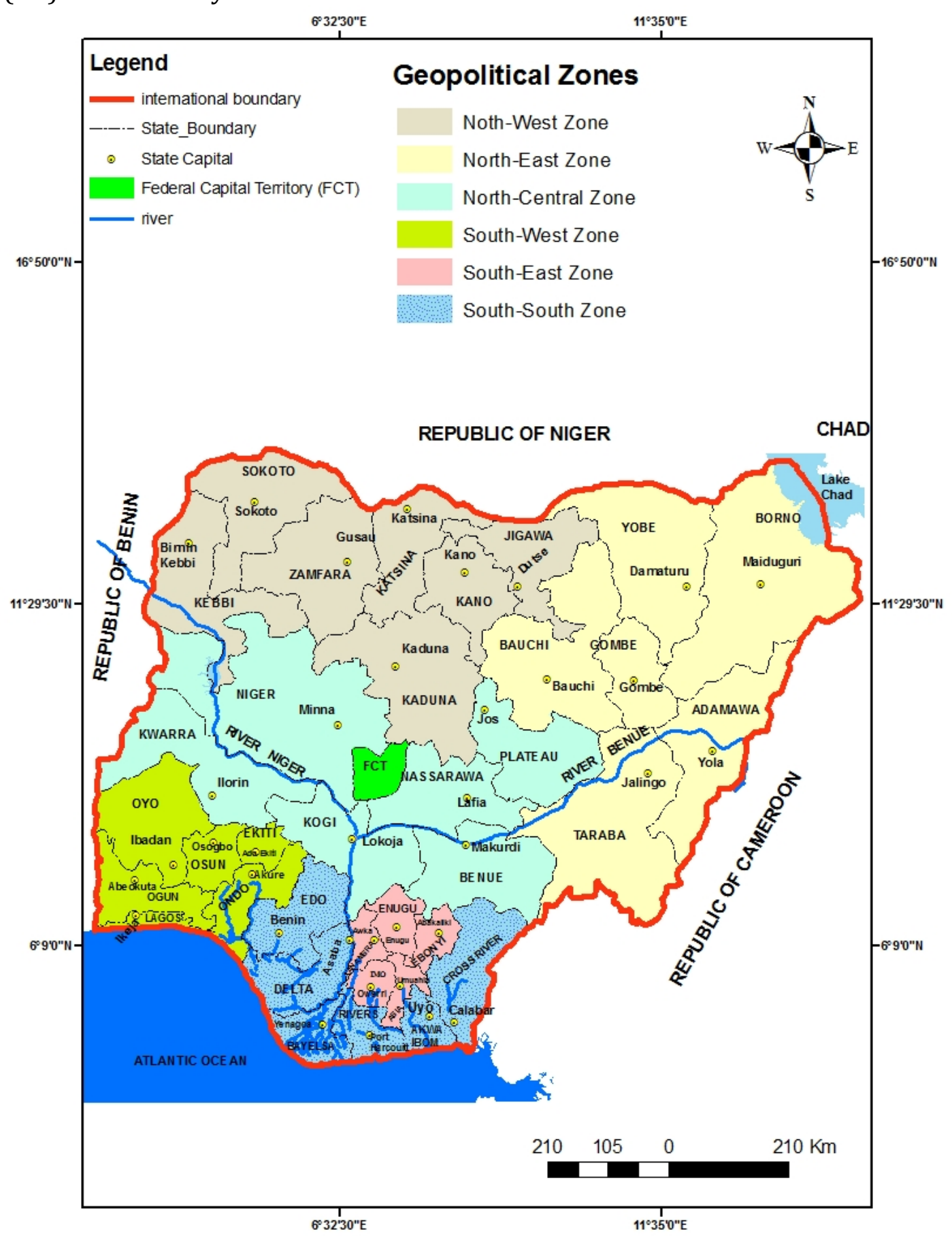

Fig. 1: Map of Nigeria showing the six geo-political zones 


\begin{tabular}{|c|c|}
\hline South West & $\begin{array}{l}\text { Ekiti } \\
\text { Oyo } \\
\text { Ondo } \\
\text { Ogun } \\
\text { Osun } \\
\text { Lagos }\end{array}$ \\
\hline South-South & $\begin{array}{l}\text { Akwa Ibom } \\
\text { Bayelsa } \\
\text { Cross River } \\
\text { Delta } \\
\text { Edo } \\
\text { Rivers }\end{array}$ \\
\hline South-East & $\begin{array}{l}\text { Abia } \\
\text { Anambra } \\
\text { Enugu } \\
\text { Ebonyi } \\
\text { Imo }\end{array}$ \\
\hline North-West & $\begin{array}{l}\text { Sokoto } \\
\text { Kebbi } \\
\text { Katsina } \\
\text { Kaduna } \\
\text { Kano } \\
\text { Zamfara } \\
\text { Jigawa }\end{array}$ \\
\hline North-Central & $\begin{array}{l}\text { Niger } \\
\text { Kwara } \\
\text { Plateau } \\
\text { Benue } \\
\text { Nasarrawa } \\
\text { Kogi } \\
\text { FCT }\end{array}$ \\
\hline North-East & $\begin{array}{l}\text { Yobe } \\
\text { Borno } \\
\text { Adamawa } \\
\text { Taraba } \\
\text { Bauchi } \\
\text { Gombe }\end{array}$ \\
\hline
\end{tabular}

Fig.2 States in each of the six geo-political zones in Nigeria.

Each cluster was numbered uniquely from 1 to 6 . This forms the first-stage sampling units from where a sample of the unit was taken using the simple random sampling technique. The sample fraction selected for this was 50 per cent. According to Udofia (2011), a sample fraction of is deemed satisfactory as no serious research can progress with sampling fraction of less than 10 per cent. Fifty per cent of six is three. The geo-political zones or strata selected through this process were: South-West, North-Central and South-South. 
In a related study, Efiong (2015) (in preparation) adopted federal universities where Accounting courses are offered in the three geographical zones as the next stage in the sampling process. These universities and the states where they are situated are found in Table 1. Mimistries and Agencies of government in these states were now used as the basic unit of sampling.

Table 1 selected zones, States and federal university offering Accounting courses

\begin{tabular}{|c|c|c|}
\hline Zones & State & $\begin{array}{l}\text { Federal University offering } \\
\text { Accounting Courses }\end{array}$ \\
\hline \multirow[t]{2}{*}{ South- West } & Lagos & University of lagos \\
\hline & Osun & Obafemi Awolowo Univeristy \\
\hline \multirow[t]{4}{*}{ South- South } & Akwa Ibom & University of Uyo \\
\hline & Cross River & University of Calabar \\
\hline & Edo & University of Benin \\
\hline & Rivers & University of Port Harcourt \\
\hline \multirow[t]{3}{*}{ North-Central } & Kwara & University of Ilorin \\
\hline & Plateau & University of Jos \\
\hline & FCT & University of Abuja \\
\hline
\end{tabular}

The number of government ministries and agencies in the different States and the Federal Capital Territory (FCT), Abuja are shown in Table 2. This information was obtained from the Ministry of Information of the different State Governments and the FCT.

Table 2: Number of Ministries and Agencies in the Selected States

\begin{tabular}{|l|c|c|}
\hline State & $\begin{array}{c}\text { Number } \\
\text { of Ministries/Agencies }\end{array}$ & Number of Samples \\
\hline Akwa Ibom & 54 & 108 \\
Cross River & 48 & 96 \\
Edo & 51 & 102 \\
Osun & 39 & 78 \\
Kwara & 46 & 92 \\
Lagos & 67 & 134 \\
Plateau & 45 & 90 \\
Rivers & 56 & 112 \\
FCT, Abuja & 82 & 164 \\
\hline Total & $\mathbf{4 8 8}$ & $\mathbf{9 7 6}$ \\
\hline
\end{tabular}

Table 2 shows the number of ministries and agencies of government in the various States and the FCT is 488. The Chief Financial Officer and the Head of the internal Audit in each of the agencies and ministries were considered as key players in the use of forensic accounting techniques in fraud prevention and detection in the organisation, hence, these two officers were selected for sampling. This also serves to provide a check on the responses given from 
each establishment to ensure internal consistency in the data. The total number of samples in each unit was therefore multiplied by 2 resulting to 976 for the entire practitioners.

This study adopts the survey strategy using the questionnaire as research instrument.

The questionnaire had 3 sections with 60 variables. Section A labelled 'demographic attributes' had 6 variables. Section B measures 'use of fraud detection and prevention mechanisms' with 27 variables and section $\mathrm{C}$ measures 'perceived effectiveness of fraud detection and prevention mechanisms' also with 27 variables.

Sections B \& C contain rating questions either as frequency ("always", "often", "rarely", "never", and "indifferent") or likelihood ("very effective", "effective", "ineffective", "very ineffective", and "neither effective nor ineffective") respectively.

A total of 976 copies of questionnaire were administered on practitioners of which 588 usable copies were retrieved. This gives a response rate of 60.25 per cent. The data were analysed using both descriptive and inferencial statistics .

\section{RESULTS}

Table 3 shows the perceived effectiveness of the fraud prevention and detection mechanism by practitioners. Fraud prevention and detection mechanisms are ranked from the most effective to the least effective. Table 3 reveals that the most effective fraud detection and prevention mechanism as perceived by practitioners were, the use of forensic accountants, data mining, virus protection, fraud prevention and detection training, the use of firewalls, fraud auditing and bank reconciliation. Also, the least effective of the mechanisms as perceived by the practitioners include staff rotation policy, corporate code of conduct and ethics policy, use of ethics officers, fraud vulnerability reviews.

Table 3: Ranking of perceived effectiveness of fraud prevention and detection mechanisms

\begin{tabular}{|l|l|l|l|}
\hline $\begin{array}{l}\text { Fraud prevention and } \\
\text { detection mechanism }\end{array}$ & N & Mean & Rank \\
\hline Forensic accountants & 588 & 3.8435 & 1 \\
\hline Data mining & 587 & 3.3356 & 2 \\
\hline Virus protection & 585 & 3.3299 & 3 \\
\hline Fraud prevention and detection training & 586 & 3.2918 & 4 \\
\hline Password protection & 587 & 3.2828 & 5 \\
\hline Firewalls & 587 & 3.2555 & 6 \\
\hline Fraud auditing & 585 & 3.1863 & 7 \\
\hline Bank reconciliations & 587 & 3.0443 & 8 \\
\hline Digital analysis Benford law & 587 & 2.9693 & 9 \\
\hline Increase role of audit committee & 586 & 2.9334 & 10 \\
\hline Ethics training & 587 & 2.9302 & 11 \\
\hline Inventory observation & 586 & 2.8857 & 12 \\
\hline Financial ratios & 586 & 2.7560 & 13 \\
\hline $\begin{array}{l}\text { Code of sanctions against suppliers } \\
\text { and contractors }\end{array}$ & 587 & 2.7359 & 14 \\
\hline Security department & & & \\
\hline Fraud reporting policy & 588 & 2.6769 & 15 \\
\hline Whistle blowing & 588 & 2.5187 & 16 \\
\hline Surveillance equipment & 588 & 2.5136 & 17 \\
\hline & 586 & 2.5051 & 18 \\
\hline
\end{tabular}




\begin{tabular}{|l|l|l|l|}
\hline Internal control & 588 & 2.4439 & 19 \\
\hline Discovery sampling & 588 & 2.4354 & 20 \\
\hline Reference check on employees & 588 & 2.3844 & 21 \\
\hline Operational audits & 588 & 2.3844 & 22 \\
\hline Fraud hotline & 588 & 2.3418 & 23 \\
\hline Fraud vulnerability reviews & 587 & 2.3288 & 24 \\
\hline Ethics officer & 587 & 2.2794 & 25 \\
\hline Corporate code of conduct and ethics policy & 587 & 2.1039 & 26 \\
\hline Staff rotation policy & 587 & 2.1022 & 27 \\
\hline Valid N (list wise) & 572 & & \\
\hline
\end{tabular}

On the other hand, the actual usage of fraud prevention and detection mechanisms by these practitioners (or in their units) is presented in Table 4.

Table 4 reveals that operational audit with rank number 1 is the most frequently used fraud detection and prevention mechanism. This is closely followed by corporate code of conduct, internal control, bank reconciliations, inventory observation and reference check on employees. The least frequently used are forensic accountants, virus protection, data mining and firewall.

Table 4 Ranking of the actual use of fraud prevention and detection mechanisms

\begin{tabular}{|l|l|l|l|}
\hline $\begin{array}{l}\text { Fraud prevention and detection } \\
\text { Mechanism }\end{array}$ & N & Mean & Rank \\
\hline Operational audit & 587 & 3.7717 & 1 \\
\hline Corporate code of conduct & 587 & 3.7513 & 2 \\
\hline Internal control & 588 & 3.7007 & 3 \\
\hline Bank reconciliations & 588 & 2.7551 & 4 \\
\hline Inventory observation & 588 & 2.6020 & 5 \\
\hline Reference check on employees & 587 & 2.5707 & 6 \\
\hline Security department & 588 & 2.5544 & 7 \\
\hline Staff rotation policy & 588 & 2.5238 & 8 \\
\hline Password protection & 585 & 2.4427 & 9 \\
\hline Increased role of audit committee & 588 & 2.3214 & 10 \\
\hline Financial ratios & 588 & 2.2959 & 11 \\
\hline Fraud reporting policy & 588 & 2.2551 & 12 \\
\hline Ethics officer & 588 & 2.0697 & 13 \\
\hline $\begin{array}{l}\text { Code of sanctions against } \\
\text { suppliers contractors }\end{array}$ & 588 & 2.0527 & 14 \\
\hline Surveillance equipment & & & \\
\hline Fraud vulnerability reviews & 587 & 2.0153 & 15 \\
\hline Whistle blowing policy & 588 & 1.7687 & 16 \\
\hline Ethics training & 588 & 1.5850 & 17 \\
\hline Digital analysis Benford Law & 588 & 1.5442 & 18 \\
\hline Fraud hotlines & 588 & 1.3759 & 19 \\
\hline Discovery sampling & 588 & 1.3129 & 20 \\
\hline Fraud auditing & 586 & 1.2543 & 21 \\
\hline Fraud prevention and detection training & 587 & 1.0443 & 22 \\
\hline
\end{tabular}




\begin{tabular}{|l|l|l|l|}
\hline Firewalls & 587 & .9676 & 24 \\
\hline Data mining & 587 & .9608 & 25 \\
\hline Virus protection & 587 & .9506 & 26 \\
\hline Forensic accountants & 587 & .9404 & 27 \\
\hline Valid N (list wise) & 580 & & \\
\hline
\end{tabular}

One hypothesis was tested in this study. It is stated here as follows:

Ho: There is no significant difference between the perceived effectiveness of fraud prevention and detection mechanisms, and their actual usage in Nigeria.

H1: There is a significant difference between the perceived effectiveness of fraud prevention and detection mechanisms, and their actual usage in Nigeria.

In testing hypothesis, $\mathrm{t}=(26)=3.45, \mathrm{p}<0.05)$ reveals that significant difference exists in the perceived effectiveness of fraud detection and prevention mechanism and their perceived usage in fraud prevention in Nigeria (Table 5).

Table 5: Difference in use and effectiveness of fraud prevention and detection mechanisms

\begin{tabular}{|c|c|c|c|c|c|c|c|c|}
\hline & \multicolumn{5}{|c|}{ Paired Differences } & \multirow{3}{*}{$\mathbf{T}$} & \multirow{3}{*}{ df } & \multirow{3}{*}{$\begin{array}{l}\text { Sig. } \\
(2- \\
\text { tailed) }\end{array}$} \\
\hline & \multirow[t]{2}{*}{ Mean } & \multirow[t]{2}{*}{$\begin{array}{c}\text { Std. } \\
\text { Deviation }\end{array}$} & \multirow[t]{2}{*}{$\begin{array}{l}\text { Std. } \\
\text { Error } \\
\text { Mean }\end{array}$} & \multicolumn{2}{|c|}{$\begin{array}{l}95 \% \text { Confidence } \\
\text { Interval of the } \\
\text { Difference }\end{array}$} & & & \\
\hline & & & & Lower & Upper & & & \\
\hline $\begin{array}{c}\text { PERCEIVEDEFFE - } \\
\text { ACTUALUSAGE }\end{array}$ & .79995 & 1.20462 & .23183 & .32342 & 1.27648 & 3.451 & 26 & $.002 *$ \\
\hline
\end{tabular}

\section{DISCUSSION OF FINDINGS}

The objective of this study was to investigate the mechanisms of fraud prevention and detection and their perceived levels of effectiveness in Nigeria. To carry out this investigation in a direct manner, the question, "what are the common fraud prevention and detection mechanisms and their perceived level of effectiveness in Nigeria is there any significant difference?" was posed. Data were collected and analysed using appropriate techniques.

From the data analysis in, various fraud detection mechanisms in actual usage in Nigeria have been identified. The study revealed that operational audit and systems of internal controls are the most frequently use fraud detection and prevention mechanisms. This is closely followed by other fraud mechanisms including corporate code of conduct, bank reconciliations, inventory observation and reference check on employees, in their order of decreasing usage. The least frequently used as identified in the present study are forensic accountants, virus protection, data mining and firewall. These findings are similar to those of Bierstaker, Brody and Pacini, (2006). The fraud prevention and detection mechanism that are commonly used in preventing and detecting financial fraudulent activities as revealed in this study are the traditional accounting and auditing methods. It has been discussed earlier that fraudulent activities have become so sophisticated and it will take a sophisticated mechanism, like the forensic accounting, to tackle. Yet, forensic accounting techniques are far from being familiar in Nigeria and particularly in the public service. Moreover, the findings of this study and available literature reveal that the use of forensic accountants, virus protection, firewalls, passwords and data mining are more effective mechanisms than operational audits, corporate code of conduct, internal control, and the rest that are used more frequently. 
There appears to be clear differences in the effectiveness of fraud detection and prevention mechanisms and their actual usage in fraud prevention. For example, the use of forensic accountants' ranks number one in effectiveness, but it is the least used mechanism in fraud prevention and detection in Nigeria. This observation agrees with the findings of Bierstaker, Brody and Pacini, (2006) that the most effective fraud prevention methods were the least used in combating the menace in the United States of America. This was confirmed by the Student's $t$ test, which reveals that significant difference exists in the effectiveness of fraud detection and prevention mechanisms and their actual usage in fraud prevention in Nigeria.

Traditional accounting methods like systems of internal controls have been found to be ineffective in fraud detection and prevention. This findings have support in the work of Muslimat and Hamid (2012) who discovered that internal audit staff lacks the basic knowledge of fraud detection and prevention. The continuous dependence on traditional methods against conventional fraud detection and prevention techniques, like the forensic accounting will not only continue to increase fraud incidence in the public service and even other sectors of the economy, but also affect general development in the country.

The foregone discussion has therefore provided answers to the research question, "what are the common fraud prevention and detection mechanisms and their levels of effectiveness in Nigeria? Is there any significant difference?" But why should the most effective fraud prevention and detection mechanism be the least used in combating the menace of fraud in Nigeria? The next section of the discussion seeks to answer the question.

\section{CONCLUSION}

Various mechanisms of fraud prevention and detection in usage were identified. The most common ones included operational audit, corporate code of conduct, internal controls, bank reconciliations, and inventory observations while the least used methods were forensic accountants, virus protection, data mining, fraud prevention and detection training, fraud auditing and digital analysis by Benford's law. It was rather shocking to discover that the perceived most effective mechanisms of forensic accountants, data mining, virus protection, fraud prevention and detection training, etc were the least currently used in Nigeria. The lack of use of these better, effective methods may be connected with the lack of awareness and nonavailability of experts.

In view of the findings of this study and to ensure that all hands are on deck to reduce financial frauds in Nigeria and elsewhere, it is recommended that organisations should adopt the most effective mechanisms in their fraud prevention and detection drive. This is because the study has shown that current fraud prevention and detection mechanisms commonly used are perceived as the least effective in combating fraud menace. Forensic accounting mechanisms and the use of forensic accountants which have been perceived most effective methods should be encouraged at all levels of government local, state and federal.

\section{References}

Adefila, J. J., Kasum, A. S. and Olaniyi, T. A. (2005) The global endemic nature of financial malpractices: an analytical appraisal. African Journal Of Management, 1 (1), pp11 - 20.

Akindele, R.I. (2011) Frauds as a negative catalyst in the Nigerian banking industry. Journal of Emerging Trends in Economics and Management Sciences (JETEMS), 2 (5), pp 357-363.

Albrecht, C. and Albrecht, U. (2004) Strategic fraud detection: a technology-based model. New York: Longman. 
Efiong, E. J., Inyang, I. O., \& Joshua, U. (2016). Effectiveness of the Mechanisms of Fraud Prevention and Detection in Nigeria. Advances in Social Sciences Research Journal, 3(3) 206-217.

Albrecht, W., Albrecht, C., and Albrecht, C. C. (2008) Current trends in fraud and its detection. Information Security Journal: A Global Perspective, 17(1),2-12. doi:10.1080/19393550801934331

Anyadike, R. N. C. (2009) Statistical methods for social and environmental sciences. Ibadan, Nigeria: Spectrum Books Limited.

Berry, J. (2003) Assume nothing audit instead. Computerworld, 14 (37), 43.

Bhasin, M. (2013) Survey of skills required by forensic accountants: evidence from a developing country. International Journal of Contemporary Business Studies, 4 (2), pp. 54 - 86.

.Bierstaker, J. L., Brody, R.G. and Pacini, C. (2006) Accountants perceptions regarding fraud detection and prevention methods. Managerial Auditing Journal, 21 (5), pp520-535.

Bierstaker, J. L., Burnaby, P. and Hass, S. (2004) Internal auditors' fraud prevention and detection methods. Internal Auditing, 19.3 (May/Jun), pp. $37-40$.

Crowther, D. and Lancaster, G. (2009) Research methods: a concise introduction to research in management and business consultancy. 2nd ed. London: Elsevier Ltd.

DiGabriele, J. A. (2008) An empirical investigation of the relevant skills of forensic accountant. Journal of Education for Business, July/August, 2008, 331- 338.

Efiong, et al. (in preparation) Readiness of Nigerian universities in taking up forensic accounting courses.

Eiya, O., and Otalor, J. I. (2013) Forensic accounting as a tool for fighting financial crime in Nigeria. Research Journal of Finance and Accounting, 4(6).18-25.

Ernst and Young. (2006) Fraud and Forensic accounting and the investigator. Kessler international publication

Ghosh, I. and Banergie, K.K. (2011) Forensic accounting - another feather in the hat of accounting. The Chartered Accountant, October, $60-63$.

Gray, D. (2008) Forensic accounting and auditing: compared and contrasted to traditional accounting and auditing. American Journal of Business Education, Fourth Quarter, 1 (2), 115 - 126.

Graziano, A.M. and Rawlin, M. L. (2004) Research Methods: A Process of Enquiry. 5th ed. Harlow: Pearson Education Group p. 77

Hamilton, D. I., \& Gabriel, J. M. O. (2012). Dimensions of fraud in Nigeria quoted firms. Am. J. Soc. Mgmt. Sci, 3(3), 112-120.

Hassibi, D. (2000) Detecting payment and fraud with new neural network. Singapore: Longman.

Hogan, C.E., Rezaee, Z., Riley, R.A. and Velury, U.K. (2008) Financial statement fraud: insights from the academic literature. Auditing: A Journal of Practice and Theory, 27 (2), 231-252.

Hopwood, W. S., Leiner, J.J., and Young, G. R.(2012), Forensic Accounting and Fraud Examination. 2nd ed. New York: McGraw-Hill.

International Standards for Professional Practice of Internal Auditing (2002) Report of International Standards for Professional Practice of Internal Auditing. Florida: The Institute of Internal Auditors.

Jeremiah, M. (2006) Nigerian dwindling economy. Journal of Business Research. 11, 26-30.

Kasum, A. S. (2009, June). The relevance of forensic accounting to financial crimes in private and public sectors of third world economies: A study from Nigeria. In The 1st International Conference on Governance Fraud Ethics and Social Responsibility (15 April 2009).

Kirkos, E., Spathis, C., \& Manolopoulos, Y. (2007) Data mining techniques for the detection of fraudulent financial statements. Expert Systems with Applications, 32(4), 99-1003.

Kumar, R. (2005) Research methodology: a step-by-step guide for beginners. 2nd ed. London: Sage Publication. Levanti, M. (2001) Prevention of Fraud. Crime Prevention Paper 17. London.

Mackeičius, J. and Kazlauskienè, L. (2009) The fraud tree and its investigation in audit. Ekonomika, 85, 90 - 101.

Mehta, G. S. and Mathur, T. (2007) Preventing Financial Fraud through 'Forensic Accounting'. The Chartered Accountant, $1575-1580$

Muslimat, A. and Hamid, K.T. (2012) The role of internal audit unit in fraud prevention in government owned hospitals in a Nigerian. IOSR Journal of Business and Management, 2 (5), 39 - 44. 
Nigrini, M. J. (1994) Using digital frequencies to detect fraud. The white Paper, 3 - 6.

Njanike, K, Dube, T. and Mashayanye, E. (2009) The effectiveness of forensic auditing in detecting, investigating and preventing bank fraud. Journal of Sustainable Development in Africa, 10 (4), 405 - 425.

Nnamdi, A. (1991) Research methodology in behavioural sciences. Lagos: Longman Nigeria Ltd

Nwachukwu, C. C. (1995) Modern Nigerian business law. Owerri, Nigeria: African Educational Services.

Nwankwo, G. O. (1991) Bank Management: Principles and Practice. Lagos: Malthouse Press.

Nwannekanma, B. (2013) Ajudua remanded in prison over alleged \$1.69m fraud. Guardian,11th June.

Okoye, A.E. and Jugu, Y.G. (2009) Effectiveness of fraud deterrence policies: a critical examination of the banking sector in Nigeria. The Nigerian Accounting Horizon, 8 (5), 154 - 169.

Okunbor, J.A. and Obaretin, O. (2010) Effectiveness of the application of forensic accounting services in Nigeria corporate organisations. AAU JMS, 1 (1), 171 - 18.

O’leary, Z. (2005) Researching real-world problems: a guide to methods of inquiry. London: Sage Publication Ltd.

Ramaswamy, V. (2011) New frontiers: Training forensic accountants within the accounting program. Journal of College Teaching \& Learning (TLC), 4(9),31-38

Ramamoorti, S. and Olsen, W. (2007)Fraud :the Human Factor. Financial Executive,53-55.

Ramaswamy, V. (2005) Corporate Governance and the Forensic Accountant. CPA Journal, 75(3),68-70.

Ratlift, R. L.,et al,(1996) Internal Auditing: Principles and Techniques. 2nd ed. Florida: The Institute of Internal Auditors.

Robertson, J. C. ( 1976) Fraud awareness auditing. Chicago: Richard D. Irwin.

Shaw, M. J.,et al (2001) Knowledge management and data mining for marketing. Decision support systems, 31(1), 127-137.

Sydney, I. F. (1986) Management control system and the prevention and detection of frauds in banks. Lagos: CIBN and Landmark Publication Ltd.

Thisday Newspaper (2009). Nigeria: The Harvest of Fraud. Editorial. Published 1 June, 2009.

Udofia, E. P. (2011) Applied statistics with multivariate methods. Enugu: Immaculate Publications Ltd.

Wells, J. (1990) Six common myths about fraud. Journal of Accountancy, 82 - 88. 